\title{
PROPOSALS FOR CHANGES IN SURVEYING-LEGAL PROCEDURES FOR THE NEEDS OF CADASTRE IN POLAND
}

\author{
Monika Mika \\ University of Agriculture in Krakow, Poland \\ Department of Land Surveying
}

\begin{abstract}
The aim of this paper is to present the need for changes of geodetic-legal procedures for the cadastre and real estate management. This problem was analyzed both in theoretical and practical terms. In order to better present the analyzed technical and legal procedures, a study of several cases of surveying documentation was made. On their example the problems associated with the surveying services were shows and the formal and legal procedures, on the basis of which described surveying works were done were verified. The problem presented is current and valid not only for the comfort of the surveyor's work, but also from the point of view of the structure and modernization of the real estate cadastre, constituting the backbone of the real estate management. The article emphasized the need to unify the databases of state registers and the digitization of the National Geodetic and Cartographic Resources (PZDGiK). Research has shown that despite the continuous changes of legislation, there are still many shortcomings and gaps, which often complicate the surveying works. The surveyor must analyze and verify all materials he uses, including those obtained from the Centre of Geodetic and Cartographic Documentation (ODGiK). The quality of the geodetic and cartographic elaboration depends largely on the work of the Centre of Geodetic and Cartographic Documentation. The need of modernization of the Land and Buildings Registry, which acts as a cadastre in Poland, has been demonstrated. Furthermore, the unification of data used as reference systems both for plane coordinates and elevation has been proposed.
\end{abstract}

Keywords: surveying, real estate management, cadastre, surveying-legal procedures

\section{Introduction}

The issues of surveying work in the field of the law was presented by Hycner and others (Hycner and Hanus, 2007). Further Hycner and Dobrowolska-Wesołowska (2008) were analyzed the aspects of professional ethics. The aim of the article is to 
present the imperfection of legislation for surveying works, the theoretical and practical aspects of the creation of cadastre in Poland. The role of cadastre in Poland play databases of the land and buildings registry (EGiB). Thus defined cadastre is a public register, containing mainly data on the actual state of real estate. The legal status of the property is recorded in databases Land and Mortgage Register courts and available for review by the Electronic Platform of Land and Mortgage Registry. Cadastre forms the backbone of the real estate management and the basis for the registration of its objects in space are the results of surveying. Legislation governing the practice of the surveyors profession are regulated primarily by the Act of 17 May 1989 Surveying and Cartographic Law and the applicable implementing acts detailed in Tables 1.

The scheme of relationship between surveying, cadastre and real estate management is shown in Fig. 1. Surveying and cadastre are closely connected and their interaction depends on the quality of cadastral data. The initial material for all surveying and spatial data are descriptive of the cadastre (EGiB). In turn, the results of the survey are entered into the databases of real estate cadastre. The poor quality of input materials generates further errors, somehow causing the feedback which adversely affect all processes related to real estate processes. Surveying, cadastre and property management are run in a common legal environment. The major legal acts and regulations are listed in Table 1.

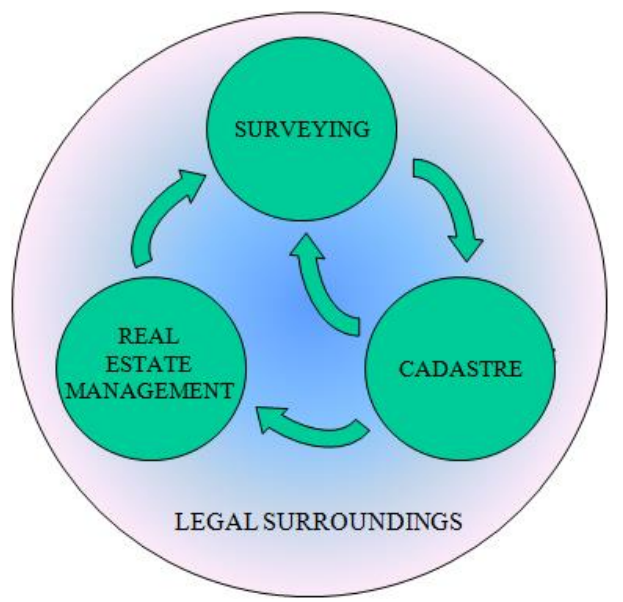

Fig. 1. The scheme of relation between, surveying, cadastre and real estate management.

Surveying works also constitute the backbone of geoinformation. A significant step in Polish geoinformation reforms was the introduction of the INSPIRE Directive (Directive 2004/17/EC of the European Parliament and of the Council of 14 March 2007 establishing the infrastructure for spatial information in Europe), which is to provide ease of gathering, sharing and exchange of spatial data between public authorities and the availability of information about these data and their possible acquisition and use. The Act on the Infrastructure of Spatial Information of 4 March 2010 is the transposition of the INSPIRE directive in Poland. It defines the rules for creation and use of spatial information infrastructure. On its basis the information about the area is collected and made available in the form of databases, including information including details on: geodetic, gravimetric and magnetic networks, EGiB, GESUT (Geodesic Registry of Infrastructure Network), state records of borders, geographical names, EMUiA (https://emuia.gugik.gov.pl/), topographic and general geographic objects. 
Table 1. The list of the most important acts and major executive acts in the field of surveying service in Poland

\begin{tabular}{|c|c|}
\hline NAME OF THE LEGAL ACT & NAME OF EXECUTIVE ACT \\
\hline $\begin{array}{l}\text { The Act of } 17 \text { May } 1989 \text { Surveying } \\
\text { and Cartographic Law }{ }^{*}\end{array}$ & $\begin{array}{l}\text { Regulation of the Minister of Infrastructure of } 12 \\
\text { April } 2002 \text { on the technical conditions that } \\
\text { should be met by buildings and their location }\end{array}$ \\
\hline $\begin{array}{l}\text { The Act of } 23 \text { April } 1964 \text { The Civil } \\
\text { Code }\end{array}$ & $\begin{array}{l}\text { The Council of Ministers Regulation of } 7 \\
\text { December } 2004 \text { on the method and procedure } \\
\text { of real estate splitting }\end{array}$ \\
\hline $\begin{array}{l}\text { The Act of } 7 \text { July } 1994 \text { Construction } \\
\text { Law }\end{array}$ & $\begin{array}{l}\text { Regulation of the Minister of Internal Affairs and } \\
\text { Administration of } 9 \text { November } 2011 \text { on technical } \\
\text { standards of performing land and height survey } \\
\text { works and the processing and transfer of } \\
\text { results of these measurements to the National } \\
\text { Geodetic and Cartographic Resources }\end{array}$ \\
\hline $\begin{array}{l}\text { The Act of } 21 \text { August } 1997 \text { on Real } \\
\text { Estate Management }\end{array}$ & $\begin{array}{l}\text { The Council of Ministers Regulation of } 15 \\
\text { October } 2012 \text { on a national spatial reference } \\
\text { system }\end{array}$ \\
\hline $\begin{array}{l}\text { The Act of } 27 \text { March } 2003 \text { on Spatial } \\
\text { Planning and Development }\end{array}$ & $\begin{array}{l}\text { Regulation of the Minister of Administration and } \\
\text { Digitization of } 5 \text { September } 2013 \text { on } \\
\text { organization and mode of the state surveying } \\
\text { and cartographic resource management. }\end{array}$ \\
\hline $\begin{array}{l}\text { The Act of } 11 \text { April } 2003 \text { on Shaping } \\
\text { of the Agricultural System }\end{array}$ & $\begin{array}{l}\text { Regulation of the Minister of Administration and } \\
\text { Digitization of } 29 \text { November } 2013 \text { amending the } \\
\text { regulation on land and buildings registry }\end{array}$ \\
\hline $\begin{array}{l}\text { The Act of } 4 \text { March } 2010 \text { on } \\
\text { Infrastructure of Spatial Information }\end{array}$ & $\begin{array}{l}\text { Regulation of the Minister of Administration and } \\
\text { Digitization of } 8 \text { July } 2014 \text { on forms for reporting } \\
\text { of surveying and cartographic works, the notice } \\
\text { of completion of the works and transfer of their } \\
\text { results to the National Geodetic and } \\
\text { Cartographic Resources }\end{array}$ \\
\hline $\begin{array}{l}\text { The Act of } 14 \text { April } 2016 \text { on } \\
\text { suspension of the sale of Agricultural } \\
\text { Property of the Treasury real estates } \\
\text { and on the amendment of certain acts }\end{array}$ & $\begin{array}{l}\text { Regulation of the Minister of Administration and } \\
\text { Digitization of } 8 \text { July } 2014 \text { on the method and } \\
\text { procedure of authentication of documents for the } \\
\text { needs of administrative, judicial or civil law } \\
\text { transactions by the bodies of Surveying and } \\
\text { Cartographic Service }\end{array}$ \\
\hline $\begin{array}{l}\text { The Act of } 6 \text { July } 1982 \text { on Land and } \\
\text { Mortgage Registers and Mortgages }\end{array}$ & $\begin{array}{l}\text { Regulation of the Minister of Administration and } \\
\text { Digitization of } 9 \text { July } 2014 \text { on the provision of } \\
\text { materials of the state surveying and cartographic } \\
\text { resource, issuing of licenses and the model of } \\
\text { Charges Calculations Document. }\end{array}$ \\
\hline $\begin{array}{l}\text { Directive 2004/17/EC of the European } \\
\text { Parliament and of the Council of } 14 \\
\text { March } 2007 \text { setting up an } \\
\text { infrastructure for spatial information in } \\
\text { European Union }\end{array}$ & \\
\hline
\end{tabular}

*The regulations requiring changes or the introduction of cross-compliance in the context of the presented research results are marked as underline 
According to the theoretical assumptions, Directive INSPIRE should already be implemented in 2/3 of sets of spatial information. In fact however, there is wide variation in the adaptation of different spatial data themes. The best level of alignment characterizes data from the Central Statistical Office, while the weakest ones are data concerning the spatial development of communes. From the point of view of surveying service, for surveyor, the most important component of spatial data are the cadastral data. Adaptation of the data to the standards of the INSPIRE directive requires to carry out surveying works that are needed to modernize the district registers. An example of the implementation of the INSPIRE Directive are web applications that allow scrolling the spatial data which are made available in accordance with the INSPIRE Directive. These applications include, among others the geoportal.gov.pl (http://www.geoportal.gov.pl 10.10.2016r.) website and WebEWID (http://geomatyka-krakow.pl 10.10.2016r.) service.

These applications, in addition to the maps data, have many features useful in the surveyor's work. These include: calculation of the area, distance, viewing descriptive information about the plots, location search by address, and many more. Unfortunately, as shown by this study - there are the centers of geodetic documentation, which do not make the module for surveyors available, although they have an integrated information system supporting geodetic and cartographic documentation center, real estate management and architecture Ewid 2007 and operating within it TurboEWID software and WebEwid portal (http://geomatykakrakow.pl 10.10.2016r.). In such centers the surveyor must settle all matters personally, submitting the necessary documents in paper form. First, he fills the application in paper form, then an employee of the National Centre of Geodesy and Cartography Documentation enters the data into the TurboEWID system, and prints form of charges, license and information about materials. The materials available electronically the surveyor can get on a data carrier and copies of the remaining materials on paper. Also, information about the geodetic control network in the area of work covered by the notification is issued in the paper form. This situation is inconvenient and troublesome for both the contractor and the workers of the center, because of the laborious and time-consuming handling of matters. The researches show, how this situation affects the quality of cartographic materials, on which are based all the processes of real estate management. For the purposes of this study, 37 randomly selected surveying documentation sets, elaborated by authorized surveyors and accepted by the National Geodetic and Cartographic Resources were verified. In each of them an initial material for the carried out surveying works was a cadastral map, on which the subsequent changes were applied. The changes here in the most of investigated cases resulted in the adoption of the new legal status of the property in question, or were a confirmation of the existing legal status, on the basis of a properly verified geodetic and legal documentation. In the half of the examined cases, the specificity of the carried out works required from the surveyor insight or use, for the purposes of these works - of historical maps, from the time of the Austrian cadastre. As a result, of all surveyed works the graphical part of the EGiB database was changed, and in some cases - also the descriptive section. All the documentation sets were prepared in accordance with the applicable surveying standards and they have suitably formulated clauses confirming their credibility and reliability of the measurements. 


\section{Materials and methods}

The most important sources of information about the terrain, which surveyor at the same time creates and uses secondary (for future works) are base maps and cadastral maps. They may be in analog or digital form as a data-base report. Much better results of work the surveyor should achieve processing and creating a digital map. In the district which is the subject of analysis, digital base and cadastral maps, together with an analogue base map in the form of drawing and matrix in the expired coordinate system 1965 are used. Moreover, in the area of research, the surveying practice shows the need to refer to historical data sources in the form of cadastral maps in 1:2880 scale. The necessity of the use of historical materials in the surveying works in Poland, has already been demonstrated in many works (Bagnicki and Mika, 2013; Kwartnik-Pruc et al., 2015; Mika and Siejka, 2012, 2014; Siejka et al., 2015; Taszakowski et al., 2016). Historical materials often contain more information and are subject to minor defects than contemporary map material in analog form. However, due to the passage of time they are subject to significant contraction of maps and mechanical defects.

\section{Results}

On the basis of the analyzes, large differences in the way of the results presentation by different groups of contractors were observed as well as differences in the composition of the individual surveying documentation sets. There were also significant drawbacks of the cartographic materials used both as source and output documents. Examples of cartographic materials defects in the research area are shown in the following figures. Figure 2 presents a destroyed matrix of a basic map in analog form, where blurred elements of map are shown. Figure 3 presents a badly matched scale of the map, where the excess of content causing its illegibility is shown. Figure 4 shows the historical material in the form of a fragment of cadastral map in the scale 1: 2880 .

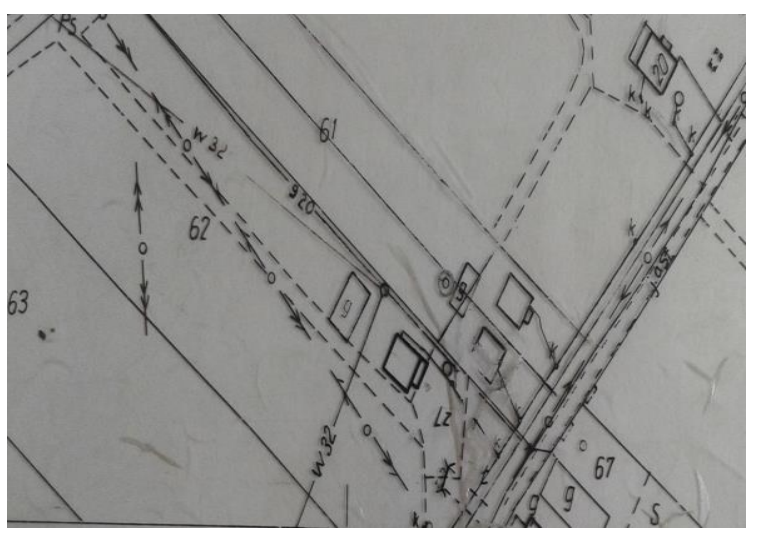

Fig. 2. Example of defective cartographic materials from the study area (own research based on PODGiK data)

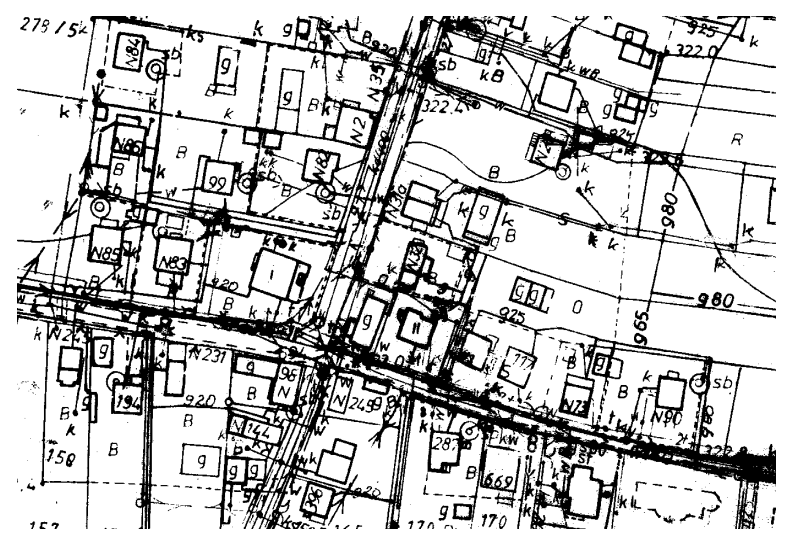

Fig. 3. Example of defective cartographic materials from the study area (own research based on PODGiK data) 


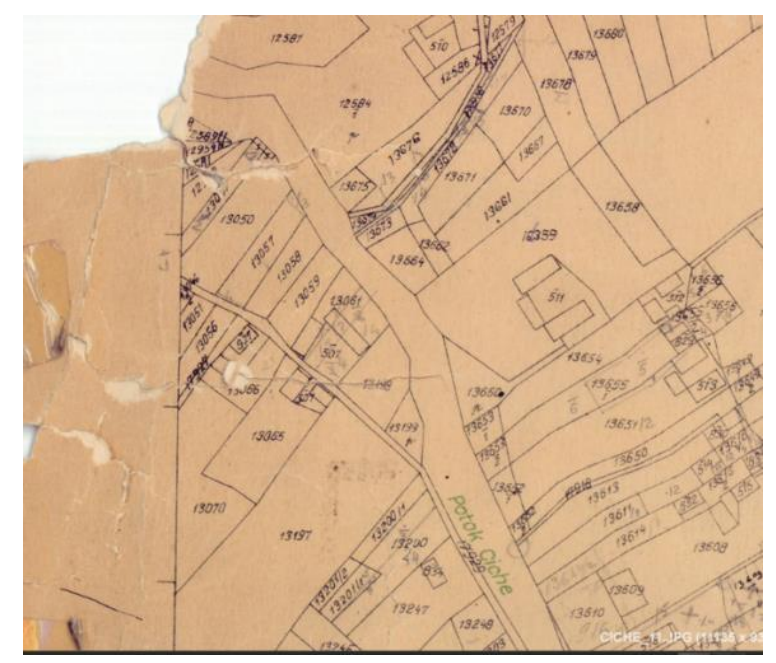

Fig. 4. Fragment of a cadastral map in the scale 1: 2880

(own research based on PODGiK data)

Subsequent processing errors burdened maps leads to a situation quite unacceptable, which influence the correct course of tasks in the field of real estate management and distort the cadastral data. This applies particularly to cadastral maps, which due to the wrong made modernization may show a number of discrepancies as to the content of other sources of information about the area, about the same objects. Examples of such maps are shown in Figures 5,6,7 and 8.

Further research has also revealed a number of discrepancies of surveying materials, between the numerical data concerning the content of the basic and cadastral maps. An example is presented in Figure 9.

During the analysis of data in the study area, significant variability of the composition of the surveying documentation and their form has been noticed. Work of a surveyor, based on poor quality materials, submitted to geodetic documentation centers in different forms, certainly will not give a fully satisfactory results from the point of view of current and future users of the cadastre. Such data interfere with the processes of real estate management.

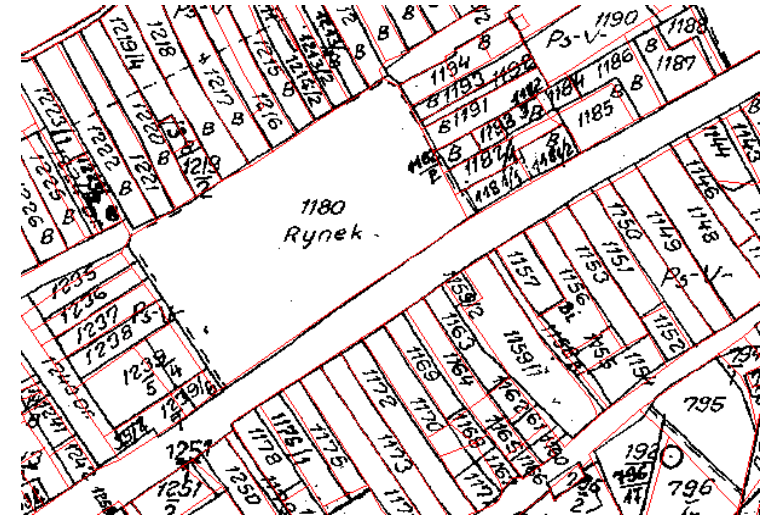

Fig. 5. Comparison of EGiB maps before and after the modernization of the registry in the built-up area (own research based on PODGiK data)

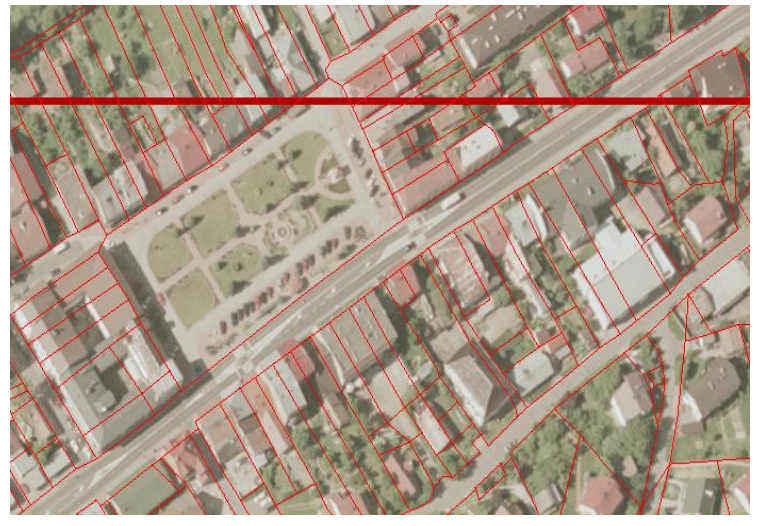

Fig. 6. Comparison of EGiB vector map after modernization with an orthophotomap in built-up areas (own research based on PODGiK data) 


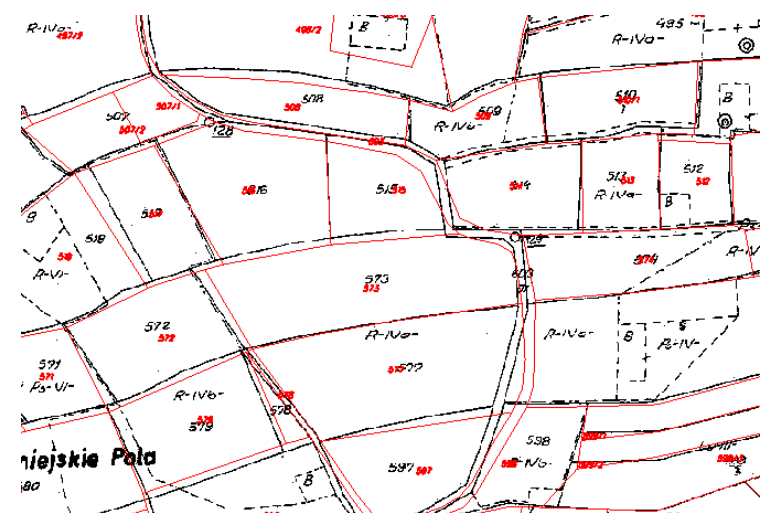

Fig. 7. Comparison of EGiB vector map before and after the modernization of the registry in the poorly invested area (own research based on PODGiK data)

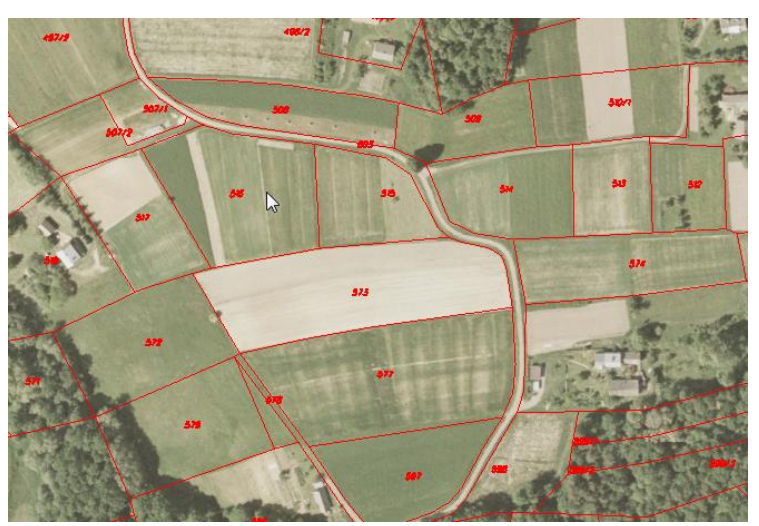

Fig. 8. Comparison of EGiB vector map after the modernization with an orthophotomap in the poorly invested area (own research based on PODGiK data)

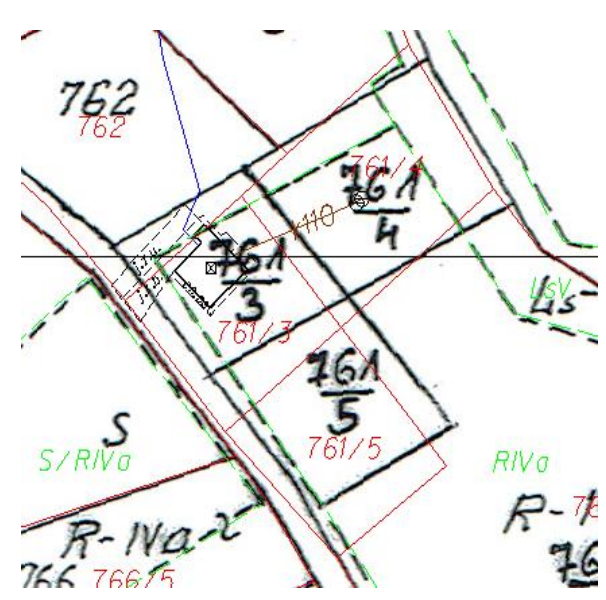

Fig. 9. Comparison of numerical data on basic map (black) with raster maps EGiB (red).

(own research based on the investigated documents)

Subject of this publication was carried out on the basis of analysis of randomly selected surveying documentation, which are part of geodetic resources, in the selected district in the Małopolska voivodship. Access to these documents was possible because of the author's cooperation with the surveying office operating in the area of research. The studied sample (37 documents sets) seems to be representative for this area due to the small number of economic objects carrying on the surveying activity there. It can be concluded, that there have been observed common trends concerning the way of surveying for this area. The names of the surveyors were repeated several times, and the results of their work have been accepted by PODGiK without objections.

A large percentage of the studied group of documentations was concerning the division of properties. From the point of view of real estate management, this process is very important. As a result of the division creates new borders. The division is a necessary stage of the investment process, because the acquisition of the whole plot of land is often uneconomical both for the investor and for the seller of the estate. Its proper conduct is closely linked with the real estate management in a given region. There are a few inconsistencies regarding its formal and legal rules. According to the 
Law on Real Estate Management, the division of property must be consistent with the provisions of the local spatial development plan. This means that in the agricultural and forestry areas it is not allowed to separate plots smaller than 0.3000 hectares, unless the separated plot is intended for the enlargement of the adjacent property or when the adjustment of borders between neighboring properties is made. In such cases, in the decision approving the division is defined the period of time, in which the transfer of property rights must take place. This period may not be longer than 6 months from the date of the legalization of division decision. Limitation of the surface of the plots separated from the agricultural land to a minimum of 0.3000 hectares and The Act of 14 April 2016 on suspension of the sale of Agricultural Property of the Treasury real estates and on the amendment of certain acts, amending inter alia The Act of 11 April 2003 on Shaping of the Agricultural System and limiting the possibility of the sale of agricultural property - significantly reduced the number of divisions of agricultural land. However, those provisions are not completely effective, because of an agricultural property with an area of 0.3000 hectares it is enough to separate 0.0001 hectares to expand the roadway or extension of adjacent property and the agricultural land with an area of less than 0.3000 hectares can be freely sold. Before creating a map authorized surveyor must accept the borders of the property being divided. Assuming the course of the borders is preceded by a study of the Land and Mortgage Register (KW) and other documents defining the legal status of the property and by the verification of the data disclosed in the real estate cadastre. In the case of non-compliance of such information data which are in accordance with the KW should be accepted. If in the Centre of Geodetic and Cartographic Documentation there are no documents defining the course of borders or data do not comply with the accuracy requirements or are unreliable, these boundaries are subject to the surveying or photogrammetric measurement. The measurements must be preceded by the demarcation of the course of borders. The documents on the basis of which the course of borders can be determined, can come from the delimitation of the property, determination of the borders of the plots, resumption and determination of border points, the real estate division, land consolidation and real estate divisions, exchange of land and court proceedings (Hanus et al., 2014). These documents are having the legal force. Determinant of the accuracy of the work is the attribute value of BPP (determining the position error of the border point), which should be 1 or 2 (the position error of not more than $0.30 \mathrm{~m}$ with respect to the network of 1 class).

The research also showed problems with identification of geodetic network points. In practice, very often, it is necessary to establish the geodetic network, due to the lack of points or insufficient state network density. It often appears that the existing geodetic control points are destroyed, deleted or moved by ignorant property owners. It is not uncommon also, that in the topographic descriptions of geodetic network points there are merely measures to borders, buildings or trees no longer existing in the terrain (figure 10). Then it is impossible to determine whether the point is correct, if there are no visible signs of damage or displacement. In this case, only the measurement supernumerary observations make it possible to detect an error. However, at the moment of finding an incompatibility, there is a need to make measurements again. 


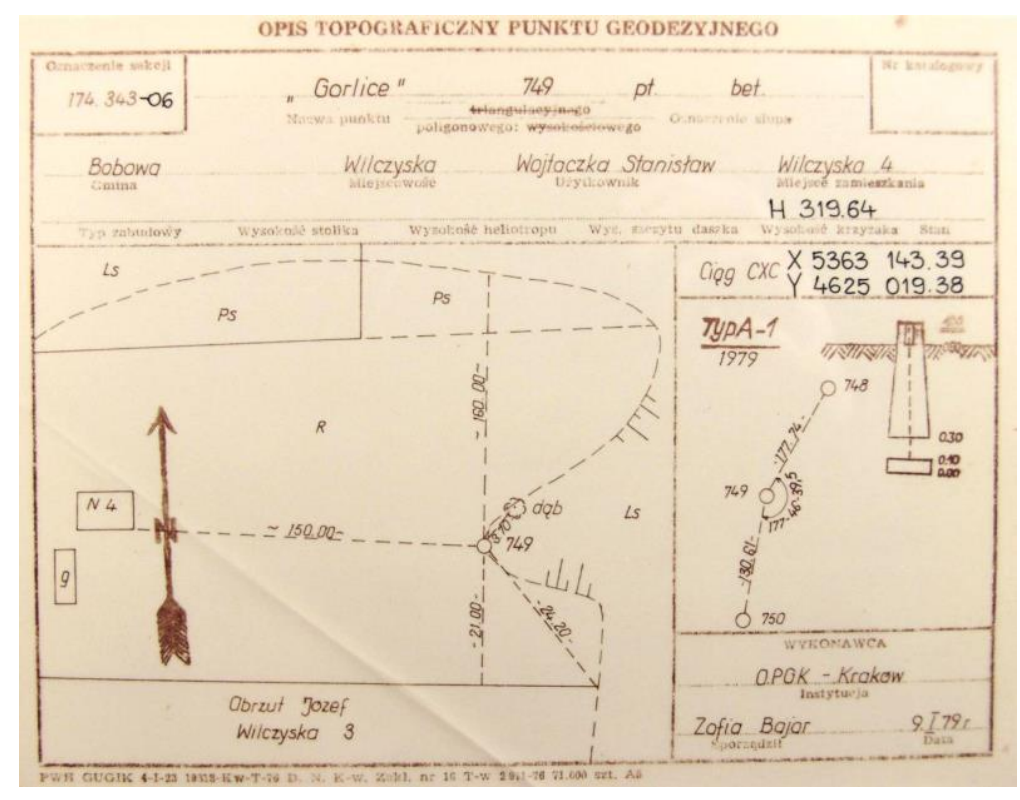

Fig. 10. An example of topographic description of geodetic network point (PODGiK)

Further problems which have been noted during the analysis of surveying documentation concerned the procedures for approval and determination of borders. Numerous cases of insufficient use of archival data, meeting the conditions for the approval of the borders were observed. Perhaps they were caused by omissions in the analysis of resource materials? To avoid this, Centers of Geodesy and Cartography Documentation should aim to digitization of resources, what eliminates the possibility of missing archive data and greatly simplifies and improves the search of resource materials. This applies to both the contractor of surveying works and to the person checking the documentation submitted to the National Centre of Geodesic and Cartographic Documentation.

Furthermore studies have shown that often in the work concerning the determination of the course of a border, the course of the border on the basis of consistent indications of the owners - differs significantly (a few or dozen meters) from the border shown in the cadastral map. These cases arouse a suspicion about the informal settlement of the borders course between the owners. Unfortunately, the surveyor many times can not state directly in the field discrepancies of the owners indications and the cadastral map. Such situations are problematic and occur especially there where the modernization of land records was not carried out and there are no vector maps.

As a part of the analysis for the purposes of this article, the authors of studied surveying documentation were interviewed. Surveyors working on the study area, often report a problem that the issue of a formal notification of the activities of acceptance and finding of borders does not settle the case, when the notified owner is dead, and information about it is determined only by the postman.

Furthermore surveyors reported a problem related to geodetic works concerning staking out objects on the ground. It has been observed, that although this work is subject to notification, the contractors often do not report the stakeout to the National Centre of Geodesic and Cartographic Documentation, and from the stakeout operations do not prepare any documents. Furthermore there is no clearly identified composition of the stakeout documentation (particularly ambiguous is the issue of staking out and documentation sketches). Another problem is that stakeout 
procedures are connected with the principal axes of the objects, while to the EGiB data the outline of the building is introduced.

Further investigation revealed the lack of legal regulations limiting the time control of the Centre of Geodesic and Cartographic Documentation of documentation submitted by surveyors after the completion of field and office works. With the repeal of 12 July 2014 of the Regulation of 16 July 2001 on the notification of surveying and cartographic works (limiting the time of control to10 days from the receiving the documents for inspection) any regulation on the issues was not introduced.

\section{Conclusions}

Despite frequent changes in legal regulations, still the lack of clear rules concerning certain geodetic tasks can be noticed. The surveyor must verify all materials he uses, including those obtained from the Centre of Geodetic and Cartographic Documentation. This issue requires an effective solution, because the carried out analysis revealed, that the quality of the geodetic and cartographic elaboration depends largely on the quality of the initial materials. On the basis of poor quality materials it is not possible to build a cadastral system that meets fully its tasks, including proper real estate management.

The following changes are necessary:

- EGiB modernization, which should be combined with the vectorization and digitization of the National Geodetic and Cartographic Resources in order to adapt data to the standards of the INSPIRE directive,

- modernization of geodetic networks and update of the coordinates based on measurements at the network points,

- specifying the timeframe of verification of documents submitted to the Centre of Geodesic and Cartographic Documentation,

- creating clear procedures for determination of borders, when the indications of property owners differ significantly from the data of the cadastral map,

- standardization of data in terms of the use of both horizontal and vertical reference systems.

The plane, rectangular coordinate system in force in the territory of Poland is the PL-2000 system. The applicable vertical system is the PL-KRON86-NH system. In practice, in many districts the maps are conducted in systems which are no longer in force. Furthermore it was observed that the surveying elaborations are performed in two horizontal systems making the appropriate transformations between systems. The vertical system is also not unified (Kronstadt'86, Kronstadt'60), and across the country an average difference of elevation is $0.05 \mathrm{~m}$ to $0.10 \mathrm{~m}$.

All the proposed changes will increase not only the comfort of surveyor work, but above all it will have positive impact on the quality of cadastre in Poland and further processes of real estate management.

\section{References}

Bagnicki J., Mika M., (2010). Analiza niezgodności danych opisowych działki (nieruchomości) na przykładzie wybranego obrębu ewidencyjnego, (Analysis of non-compliances of plot (real estate) descriptive data on the example of the 
selected cadastral precinct), Infrastruktura i ekologia terenów wielskich 2/l1/2013, pp. 99-110

Hanus P., Jasinska E., Preweda E. (2014). Analysis Of The Accuracy Of Determining The Coordinates Property Borders. 9th International Conference Environmental Engineering (9th ICEE) - Selected Papers. ISBN:978-609-457-6409. DOI: $10.3846 /$ enviro.2014.192

Hycner R., Hanus P., (2007). Wykonawstwo geodezyjne, Gall, Katowice.

Hycner R., Dobrowolska-Wesołowska M. (2008). Geodesy, Surveying and Professional Ethics, Gall, Katowice.

Kwartnik-Pruc A. (red.), Bacior S., Bieda A., Mika M., Pęska A., Siejka M., Trembecka A., Wróbel A., (2015). Rola danych geodezyjnych w wybranych procesach gospodarki nieruchomościami. Rzeszów (The role of surveying data in selected processes of property management). Wyższa Szkoła InżynieryjnoEkonomiczna.

Mika M., Siejka M., (2012). Wpływ geograficznych i historycznych uwarunkowań na identyfikację granic nieruchomości na przykładzie katastru austriackiego (The impact of the geographic and historical conditions on the identification of the borders of the property on the example of Austrian cadaster). Acta Scientiarum Polonorum. Administratio Locorum, 11(4), pp.65-74.

Mika M., Siejka M., (2014). Badanie stopnia cyfryzacji danych oraz wykorzystania map katastralnych w EGIB na obszarze wybranego powiatu w województwie podkarpackim, (Research of the digitalisation of data and the use of cadastral maps in EGiB in the area of the selected district in Podkarpackie voivodship). Infrastruktura i ekologia terenów wielskich, II/2/2014, pp.623-634.

Siejka M., Ślusarski M., Mika M., (2015). Legal and technical aspects of modernization of land and buldings cadastre in selected area, Reports on Geodesy and Geoinformatics, 99/2015, pp.44-53.

Taszakowski J., Janus J., Mika M., Leń P., (2016). Katastralne scalenia gruntów w procesie modernizacji katastru nieruchomości w Polsce, (Cadastral land consolidation in the process of modernization of the cadastre of real estate in Poland). Infrastruktura i Ekologia Terenów Wiejskich, II/I/ 2016, pp.375-394.

\section{Author:}

PhD Monika Mika, momika@ar.krakow.pl

University of Agriculture in Krakow

Department of Land Surveying

Balicka 253A Street

30-198 Cracow, Poland 